\title{
Purification and biochemical characterization of pancreatic phospholipase A2 from the common stingray Dasyatis pastinaca
}

\author{
Abir Ben Bacha ${ }^{\dagger}$, Aida Karray ${ }^{\dagger}$, Emna Bouchaala, Youssef Gargouri, Yassine Ben Ali
}

\begin{abstract}
Background: Mammalian sPLA2-IB are well characterized. In contrast, much less is known about aquatic ones. The aquatic world contains a wide variety of living species and, hence represents a great potential for discovering new lipolytic enzymes.

Results: A marine stingray phospholipase $A_{2}$ (SPLA2) was purified from delipidated pancreas. Purified SPLA2, which is not glycosylated protein, was found to be monomeric protein with a molecular mass of $14 \mathrm{kDa}$. A specific activity of $750 \mathrm{U} / \mathrm{mg}$ for purified SPLA2 was measured at optimal conditions $\left(\mathrm{pH} 8.5\right.$ and $40{ }^{\circ} \mathrm{C}$ ) in the presence of $4 \mathrm{mM} \mathrm{NaTDC}$ and $8 \mathrm{mM} \mathrm{CaCl} 2$ using PC as substrate. The sequence of the first twenty first amino-acid residues at the N-terminal extremity of SPLA2 was determined and shows a close similarity with known mammal and bird pancreatic secreted phospholipases A2. SPLA2 stability in the presence of organic solvents, as well as in acidic and alkaline $\mathrm{pH}$ and at high temperature makes it a good candidate for its application in food industry.

Conclusions: SPLA2 has several advantageous features for industrial applications. Stability of SPLA2 in the presence of organic solvents, and its tolerance to high temperatures, basic and acidic pH, makes it a good candidate for application in food industry to treat phospholipid-rich industrial effluents, or to synthesize useful chemical compounds.
\end{abstract}

\section{Background}

Phospholipases A2 (PLA2) comprise a set of extracellular and intracellular enzymes that catalyze the hydrolysis of the sn-2 fatty acyl bond of phospholipids to yield fatty acids and lysophospholipids [1]. The intracellular PLA2 s are divided into cPLA2 (cytosolic calcium dependent, group IV) and iPLA2 (cytosolic calcium independent, group VI), based on the $\mathrm{Ca}^{2+}$ requirements needed for basal activity. cPLA2 requires micromolar $\mathrm{Ca}^{2+}$ for membrane translocation but not for catalysis, possesses a preference for phospholipids containing AA, and have high molecular mass (> $60 \mathrm{kDa})$. iPLA2 exhibits no substrate specificity for AA-containing phospholipids and no $\mathrm{Ca}^{2+}$ requirement for activity and has high molecular mass (about $85 \mathrm{kDa}$ ) [1-3]. The extracellular (secreted) PLA2 s (sPLA2) have low molecular masses (13-18 kDa), require

\footnotetext{
* Correspondence: yassine_marseille@yahoo.fr

+ Contributed equally

Laboratoire de Biochimie et de Génie Enzymatique des Lipases, ENIS route de Soukra, BP1173, University of Sfax - 3038 Sfax, Tunisia
}

millimolar calcium concentrations for catalytic activity, and do not manifest significant fatty acid selectivity in vitro. To date, 11 forms of mammal sPLA2 have been identified and classified according to their origin, sequence similarity and molecular mass as well as substrate specificity into groups IB, IIA, IIC, IID, IIE, IIF, V, X, III, XIIA and XIIB $[4,5]$. There is also a class of PLA2 s called platelet-activating factor (PAF) acetylhydrolases [6].

sPLA2-IB is also known as the pancreatic-type PLA2. It is synthesized by the pancreatic acinar cells, and after secretion as a zymogen into the pancreatic juice, an $\mathrm{N}$-terminal heptapeptide of the inactive zymogen is cleaved by trypsin to yield an active enzyme in the duodenum.

sPLA2-IB is also highly expressed in the stomach and is present at lower levels in lung, spleen, liver, colon and eyes [7-9]. Receptors for this enzyme have been identified in various tissues, and group IB PLA2 is now reported to play a role in cell proliferation and hormone release via these receptors in non-digestive tissues
C Biomed Central

(c) 2011 Bacha et al; licensee BioMed Central Ltd. This is an Open Access article distributed under the terms of the Creative Commons Attribution License (http://creativecommons.org/licenses/by/2.0), which permits unrestricted use, distribution, and reproduction in any medium, provided the original work is properly cited. 
$[7,10,11]$. These findings reveal the physiological importance of group IB PLA2 in non-digestive tissues, in addition to digestive lipolysis in the intestinal tract.

Cartilaginous fish, represented by sharks, skates and rays, are generally considered as the most primitive living jawed vertebrates. They first appeared during the Ordovician period about 450 million years ago sharing a common ancestor with a jawed vertebrate ancestor, placoderm. The extinction of placoderm at DevonianCarboniferous boundary makes cartilaginous fish the oldest taxa of extant jawed vertebrates, pushing them to the edge of jawless-jawed transition. To date, the cartilaginous fish are also the oldest vertebrates possessing a complex digestif system like mammals [12].

Mammalian sPLA2-IB are well characterized [13-20] and recently some studies are carried on bird PLA2 [21-23]. In the contrast, much less is known about aquatic ones [24-30]. The aquatic world contains a wide variety of living species and, hence represents a great potential for discovering new enzymes. It is therefore interesting to study some catalytic and biochemical properties of a purified marine PLA2 to gain more insights into their action mode on phospholipids. This paper reports, for the first time, the purification of phospholipase A2 from the same organ. This phospholipase tentatively named stingray pancreatic phospholipase A2 (SPLA2) was characterized using the emulsified system.

\section{Results}

\section{Activation of SPLA2 by trypsin}

No phospholipase activity was detected in freshly crude extract of delipidated pancreas of stingray using PC emulsions (Figure 1). The maximum PLA2 activity was obtained after incubation at room temperature during 40 min, PLA2 activity did not increase when exogenous trypsin was added at different ratios to the homogenate solution then endogenous proteases are sufficient to achieve PLA2 activation (data not shown).

It has emerged from several kinetic studies on phospholipases $\mathrm{A}_{2}$ that the $\mathrm{N}$-terminal propeptide may play an important role in the expression of the maximum catalytic activity measured in vitro [31].

The most illustrative example was reported by de Haas' group on pancreatic phospholipase $A_{2}$, which is known to be secreted by the pancreas as a zymogen which is highly active on water soluble short chain phospholipids, but not able to hydrolyse long chain phospholipids present at the interface. Limited proteolysis by trypsin of the Arg7-Ala8 peptide bond transforms the inactive zymogen into an active enzyme [32].

\section{Purification of SPLA2 from the stingray pancreas}

20 grams of delipidated powder of the stingray pancreas was suspended in $300 \mathrm{ml} 50 \mathrm{mM}$ Tris- $\mathrm{HCl}$ buffer, $\mathrm{pH}$
8.5, containing $0.05 \%$ Triton X-100 and $150 \mathrm{mM} \mathrm{NaCl}$ (buffer A) and ground mechanically twice for $30 \mathrm{~s}$ using the Waring Blendor system. The mixture was stirred with a magnetic bar for $45 \mathrm{~min}$ at room temperature and then centrifuged for $30 \mathrm{~min}$ at $12,000 \mathrm{rpm}$. The supernatant contained 450 PLA2 units per gram of delipidated pancreatic tissue.

\section{- Heat and acidic treatment}

In contrast to marine snail (mSDPL) and crab (CDPL) digestive phospholipases purified recently in our laboratory $[28,30]$, SPLA2 present in the homogenate can tolerate, without any denaturation, the incubation at high temperature. The stingray extract PLA2 solution was incubated $15 \mathrm{~min}$ at $65{ }^{\circ} \mathrm{C}$. After rapid cooling, insoluble denatured proteins were removed by centrifugation during $30 \mathrm{~min}$ at $12,000 \mathrm{rpm}$. Afterward, the $\mathrm{pH}$ of the previous supernatant was brought to 3.0 by adding $6 \mathrm{~N} \mathrm{HCl}$ under gentle stirring at $0^{\circ} \mathrm{C}$. After centrifugation $(30 \mathrm{~min}$ at $12,000 \mathrm{rpm}$ ), the clear supernatant, which was adjusted to pH 7 with $6 \mathrm{~N} \mathrm{NaOH}$, contained $85 \%$ of starting amount of PLA2.

\section{- Ammonium sulfate precipitation}

The treated supernatant $(250 \mathrm{ml}, 7650 \mathrm{U})$ was brought to $70 \%$ saturation with solid ammonium sulphate under stirring conditions and maintained during $45 \mathrm{~min}$ at $4{ }^{\circ} \mathrm{C}$. After centrifugation (30 min at $12.000 \mathrm{rpm}$ ), the precipitated PLA2 was resuspended in $10 \mathrm{ml}$ of buffer A containing $2 \mathrm{mM}$ benzamidine. Insoluble material was removed by centrifugation during $10 \mathrm{~min}$ at $12.000 \mathrm{rpm}$. Approximately $68 \%$ of the starting amount of PLA2 was recovered.

\section{- Ethanol fractionation}

An equal volume of pure ethanol solution was added to the supernatant $(10 \mathrm{ml}, 6120 \mathrm{U})$ at $0{ }^{\circ} \mathrm{C}$. Precipitated proteins were removed by centrifugation and the supernatant was added slowly with four times its volume of ethanol to bring the alcohol concentration to $90 \%(\mathrm{v} / \mathrm{v})$ at $0{ }^{\circ} \mathrm{C}$. After centrifugation for $30 \mathrm{~min}$ at $12.000 \mathrm{rpm}$ the ethanol precipitated PLA2, which contains about $50 \%$ of the enzyme starting amount, was solubilized in of $100 \mathrm{mM}$ acetate buffer $\mathrm{pH} 4.5$ containing $0.05 \%$ TX-100 and $2 \mathrm{mM}$ benzamidine (buffer $\mathrm{B}$ ). In the present study, we found this step critical to eliminate the last traces of lipids facilitating the filtration chromatography step.

\section{Filtration on Sephadex G-50}

The PLA2 sample was submitted to gel filtration through a Sephadex G-50 column $(95 \mathrm{~cm} \times 2.6 \mathrm{~cm})$ equilibrated with buffer B. Elution of proteins was performed with the same buffer at $30 \mathrm{ml} / \mathrm{h}$. The fractions containing the PLA2 activity eluted between 1.5 and 2 void volumes were pooled together (data not shown). - FPLC cation exchange Mono-S Sepharose

The pooled active fractions of Sephadex G-50 column were applied to a Mono-S column $(2.6 \mathrm{~cm} \times 20 \mathrm{~cm})$ 

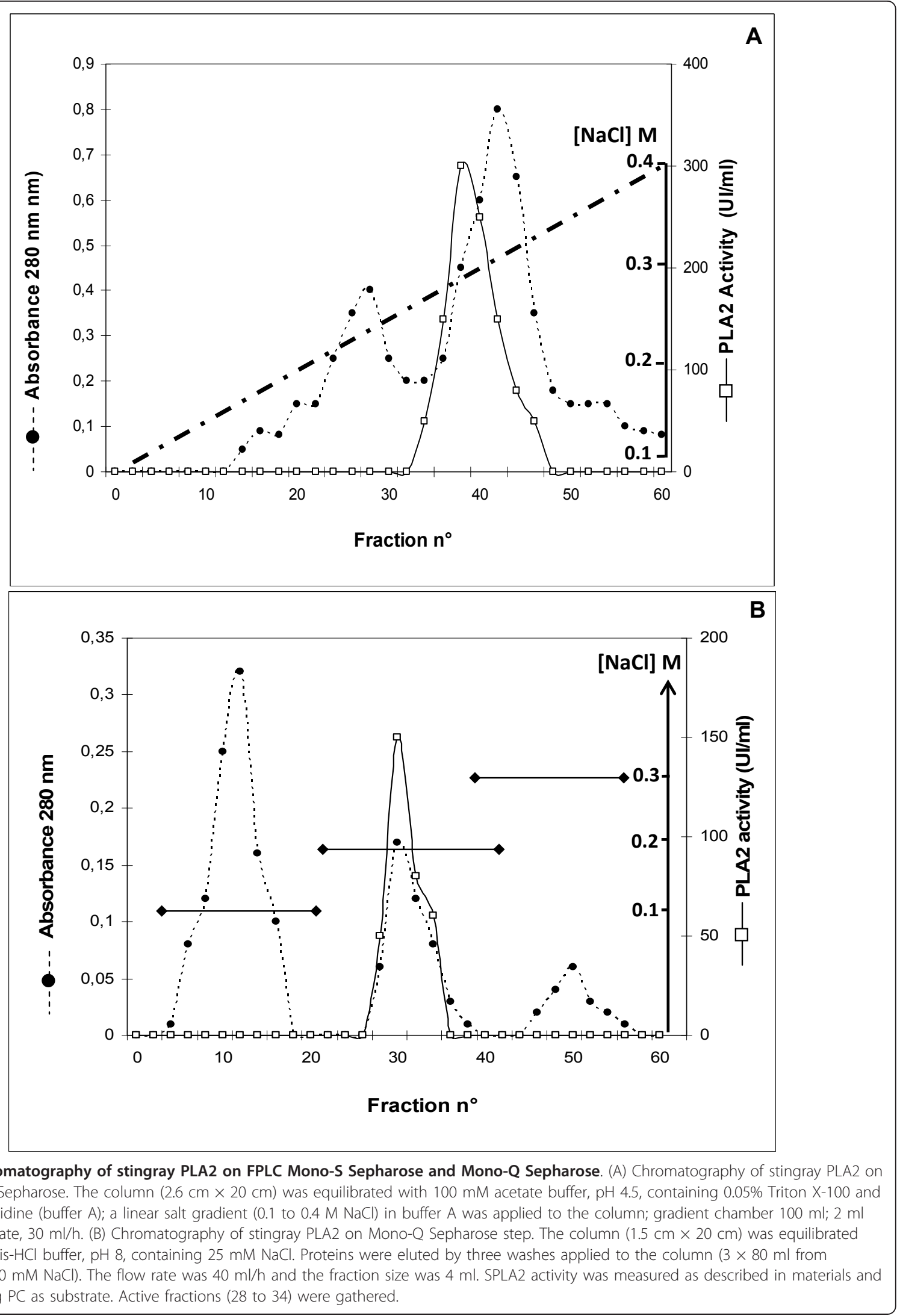

Figure 1 Chromatography of stingray PLA2 on FPLC Mono-S Sepharose and Mono-Q Sepharose. (A) Chromatography of stingray PLA2 on FPLC Mono-S Sepharose. The column $(2.6 \mathrm{~cm} \times 20 \mathrm{~cm})$ was equilibrated with $100 \mathrm{mM}$ acetate buffer, $\mathrm{pH}$ 4.5, containing $0.05 \%$ Triton X-100 and $2 \mathrm{mM}$ benzamidine (buffer A); a linear salt gradient ( 0.1 to $0.4 \mathrm{M} \mathrm{NaCl}$ ) in buffer A was applied to the column; gradient chamber $100 \mathrm{ml} ; 2 \mathrm{ml}$ fraction; flow rate, $30 \mathrm{ml} / \mathrm{h}$. (B) Chromatography of stingray PLA2 on Mono-Q Sepharose step. The column $(1.5 \mathrm{~cm} \times 20 \mathrm{~cm})$ was equilibrated with $25 \mathrm{mM}$ tris- $\mathrm{HCl}$ buffer, $\mathrm{pH}$ 8, containing $25 \mathrm{mM} \mathrm{NaCl}$. Proteins were eluted by three washes applied to the column $(3 \times 80 \mathrm{ml}$ from $100 \mathrm{mM}$ to $300 \mathrm{mM} \mathrm{NaCl}$ ). The flow rate was $40 \mathrm{ml} / \mathrm{h}$ and the fraction size was $4 \mathrm{ml}$. SPLA2 activity was measured as described in materials and methods using PC as substrate. Active fractions (28 to 34 ) were gathered. 
equilibrated with buffer B. Non fixed proteins were washed out with $0.1 \mathrm{M} \mathrm{NaCl}$ in buffer $\mathrm{B}$. The elution of the adsorbed proteins was then performed with a linear gradient of $\mathrm{NaCl}(0.1$ to $0.4 \mathrm{M})$. As shown in the elution diagram, SPLA2 activity emerged in a single peak (Figure 1A) at $0.27 \mathrm{M} \mathrm{NaCl}$. The fractions of this peak were pooled, lyophilized and then dialyzed over night at $4{ }^{\circ} \mathrm{C}$ against $25 \mathrm{mM}$ Tris $\mathrm{HCl}$ buffer $\mathrm{pH} 8$ containing $25 \mathrm{mM} \mathrm{NaCl}$ and $2 \mathrm{mM}$ benzamidine (buffer $\mathrm{C}$ ). The recovery of PLA2 from Mono-S column was of about $45 \%$ of the starting amount of the enzyme.

\section{- Anion exchange chromatography}

Dialyzed active fractions were subjected to anionexchange chromatography using a Mono-Q column $(1.5 \mathrm{~cm} \times 20 \mathrm{~cm})$ equilibrated with buffer. The column was rinsed with $100 \mathrm{ml}$ of buffer $\mathrm{C}$ containing $100 \mathrm{mM}$ $\mathrm{NaCl}$ allowed to eliminate a first peak with high absorbance. SPLA2 was eluted from Mono-Q Sepharose upon a single wash with the same buffer containing $200 \mathrm{mM}$ $\mathrm{NaCl}$. One peak was then obtained and only 8 fractions containing pure SPLA2 were pooled (figure 1B). Active fractions were pooled and lyophilized. At this stage of purification, the enzyme presented a specific activity of $550 \mathrm{U} / \mathrm{mg}$.

\section{- RP-HPLC C-8 column}

Thirty units of lyophilized sample from Mono-Q column were applied to RP-HPLC eurospher 100, C-8 column $(250 \mathrm{~mm} \times 4.6 \mathrm{~mm})$. PLA2 activity was detected in a fraction eluted at $70 \%$ acetonitrile as a single peak

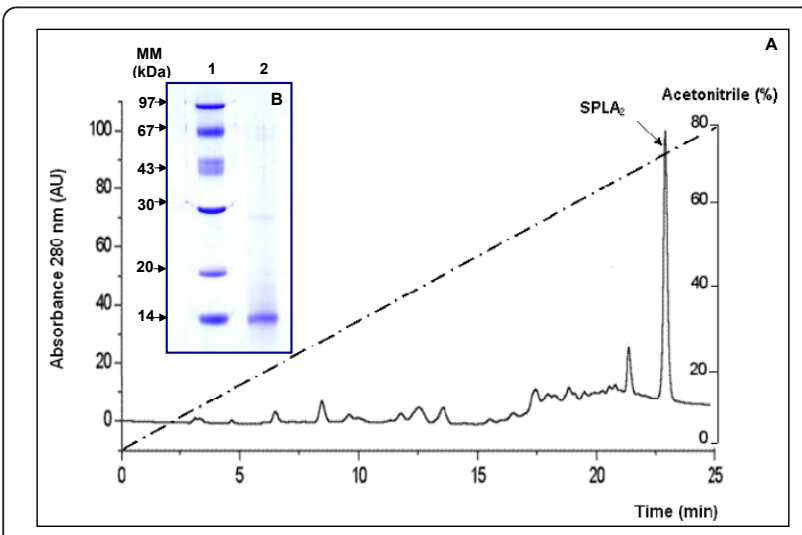

Figure 2 RP-HPLC column and SDS-PAGE (15\%) of SPLA2 (A) RP-HPLC on a eurospher 100, C-8 column, elution was performed at room temperature within $30 \mathrm{~min}$ using a gradient from 0 to $80 \%$ solvent $B$ at a flow rate of $1 \mathrm{ml} / \mathrm{min}$. [solvent $A$, water/trifluoroacetic acid (1000:1, v/v) and solvent B, acetonitrile]. The effluent was monitored at $280 \mathrm{~nm}$. The gradient is indicated by the dotted line. AU: Arbitrary Units. (B) SDS-PAGE (15\%) of pure $\mathrm{SPLA}_{2}$. Lane1, molecular mass markers (Pharmacia); lane 2, $7 \mu \mathrm{g}$ of SPLA2 eluted from RP-HPLC. The gel was stained with Comassie blue to reveal proteins.
(Figure 2A) and the overall recovery of the enzyme activity was $23 \%$ of the starting amount.

The purification flow sheet given in Table 1 shows that the specific activity of pure SPLA2 reached $750 \mathrm{U} / \mathrm{mg}$, when PC or egg yolk emulsions were used as substrates at $\mathrm{pH} 8.5,40{ }^{\circ} \mathrm{C}$ and in the presence of $4 \mathrm{mM} \mathrm{NaTDC}$ and $8 \mathrm{mM} \mathrm{CaCl}_{2}$. The fractions containing the SPLA2 activity were pooled and analysed on SDS-PAGE (Figure 2B). This figure shows that SPLA2 is homogenously pure and has an apparent molecular mass of $14 \mathrm{kDa}$. This result was in line with the molecular mass determined under native conditions, using gel filtration on FPLC column Superdex $75(1 \times 30 \mathrm{~cm})$ (data not shown). These data suggested that SPLA2 was a monomeric protein like all the sPLA2 described in previous works [13-23].

The presence of glycan chains in pure SPLA2 was checked. Our results showed that the aquatic PLA2, like mammalian and bird PLA2, is not glycosylated (data not shown) [20-23].

\section{$\mathrm{NH}_{2}$-terminal sequencing of SPLA2}

Purified SPLA2 was denaturated, reduced and alkylated as described in Section 2 and dialysed against distilled water. The $\mathrm{NH}_{2}$-terminal sequencing of the PVDF transferred band from an electrophoretic gel allowed unambiguously the identification of the twenty first $\mathrm{N}$-terminal residues of SPLA2. The same sequences were obtained when the pure SPLA2 was transferred without alkylation on a PVDF membrane. Result presented in Table 2 shows the $\mathrm{N}$-terminal sequence, of SPLA2, together with those of dromedary [20], turkey [21], ostrich [22] and chicken [23] PLA2. N-terminal sequence of marine PLA2 exhibits a high degree of homology with $\mathrm{N}$-terminal sequences of mammal and bird ones. However, no similarity of the CDPL [28] and mSDL [30] N-terminal amino acid sequences with known digestive phospholipases was found.

\section{Enzymatic properties of the purified SPLA2 Effect of temperature on phospholipase activity and stability}

Phospholipase activity was tested at temperatures ranging from 20 to $55^{\circ} \mathrm{C}$ using homogeneous $\mathrm{PC}$ emulsion as substrate (figure $3 \mathrm{~A}$ ). For the sake of comparison we also report the results for dromedary and ostrich pancreatic phospholipases in Figure 2. The maximal SPLA2 activity was measured at $40{ }^{\circ} \mathrm{C}$. This optimum was similar to that of mammal and bird pancreatic PLA2, like dromedary [20], chicken [22] and ostrich [23] but less than those of the PLA2 from the pyloric ceca of starfish A. pectinifera [33], CDLA [28] and MSDPL [30] which had optimal temperatures around $50{ }^{\circ} \mathrm{C}$.

The thermostability of SPLA2 was also investigated by measuring the residual activity after incubation of 
Table 1 Flow sheet of stingray PLA2 purification

\begin{tabular}{|c|c|c|c|c|c|}
\hline $\begin{array}{l}\text { Purification } \\
\text { step }\end{array}$ & Total $^{\text {(a) }}$ activity (units) & $\begin{array}{l}\text { Protein }{ }^{(b)} \\
(\mathrm{mg})\end{array}$ & $\begin{array}{l}\text { Specific } \\
\text { activity } \\
(\mathrm{U} / \mathrm{mg})\end{array}$ & $\begin{array}{c}\text { Activity } \\
\text { recovery } \\
(\%)\end{array}$ & $\begin{array}{l}\text { Purification } \\
\text { factor }\end{array}$ \\
\hline Extraction & 9000 & 3500 & 2.6 & 100 & 1 \\
\hline Heat and acidic treatment & 7650 & 1050 & 7.3 & 72 & 2.8 \\
\hline $\begin{array}{c}\left(\mathrm{NH}_{4}\right)_{2} \mathrm{SO}_{4} \\
\text { Precipitation } \\
(30-70 \%)\end{array}$ & 6120 & 500 & 12.3 & 68 & 4.7 \\
\hline $\begin{array}{c}\text { Ethanol fractionation } \\
(50-90 \%)\end{array}$ & 5250 & 150 & 35 & 58 & 13.46 \\
\hline $\begin{array}{l}\text { Mono-S } \\
\text { Sepharose }\end{array}$ & 4050 & 8.1 & 250 & 45 & 96 \\
\hline $\begin{array}{l}\text { Mono-Q } \\
\text { Sepharose }\end{array}$ & 2900 & 5.3 & 550 & 32 & 211.5 \\
\hline RP-HPLC & 2100 & 2.8 & 750 & 23 & 288.5 \\
\hline
\end{tabular}

(a) 1 Unit: $\mu$ mole of fatty acid released per min using PC emulsion as substrate in the presence of $4 \mathrm{mM} \mathrm{NaTDC}$ and in the presence of $8 \mathrm{mM} \mathrm{CaCl}$.

(b) Proteins were estimated by Bradford method (32). The experiments were conducted three times.

the pure enzyme at $70^{\circ} \mathrm{C}$ in buffer at different times (Figure 3B). In contrast to mSDPL, CDLA [28] and TPLA2 [21], which lose their full activities when incubated at $55{ }^{\circ} \mathrm{C}$ during a few minutes, PLA2 purified from stingray pancreas can tolerate the incubation at high temperature and maintained about $75 \%$ of its activity after $5 \mathrm{~min}$ incubation at $70{ }^{\circ} \mathrm{C}$. Similar behavior was obtained with dromedary (DrPLA2) taken as model of mammal PLA2 when incubated under the same conditions at $70{ }^{\circ} \mathrm{C}$ (Figure 3B). However, marine PLA2 was found, less resistant against temperature than the ostrich PLA2 (OPLA2) taken as a model of bird PLA2. As shown in Figure 3A, pure OPLA2 maintained about $80 \%$ of its activity after $20 \mathrm{~min}$ incubation at $70{ }^{\circ} \mathrm{C}$.

\section{Effect of $\mathrm{pH}$ on the phospholipase activity and stability}

The $\mathrm{pH}$ activity profile of the purified stingray phospholipase $\mathrm{A}_{2}$ is shown in Figure 3C. The pH-optimum of SPLA2 activity was similar to that of DrPLA2 and OPLA2 [20-23] 1760. The maximal activity of SPLA2 was measured at $\mathrm{pH} 8.5$ (Figure $3 \mathrm{C}$ ).

Moreover, the $\mathrm{pH}$ stability (Figure 3D) showed that the purified SPLA2 was found to be active between $\mathrm{pH} 3$ and 10 during $10 \mathrm{~min}$ of incubation. In contrast to OPLA2 which maintained more than $70 \%$ of its activity when incubated at $\mathrm{pH} 1.5$ the pure SPLA2 is not stable at $\mathrm{pH}$

Table 2 Alignment of the $\mathrm{N}$-terminal sequence of SPLA2 with chicken, turkey, ostrich and dromedary PLA2

\begin{tabular}{lllllll}
\hline & 1 & 5 & 10 & 15 & 20 & \\
Stingray & :AIFEF & RSMIK & CTIPP & SSPIL & D & This study \\
Chicken & :ALWEF & RSMIK & CAIPH & SHPFL & E & $(23)$ \\
Ostrich & :AVWQF & REMIK & CTIPP & SDDLL & D & $(22)$ \\
Dromedary & $:$ ALWQF & RDMIK & CKIPD & SSPLL & D & $(20)$ \\
Turkey & :ALFEF & RSMIK & CTIPG & SDPEL & D & $(21)$ \\
\hline
\end{tabular}

Residues in bold indicate identical amino acids. less than 3, (Figure 3D). However, the TPLA2 [21], mSDL [30] and CDPL [28] lose their full activity when incubated at $\mathrm{pH}$ less than 5 for few minutes.

\section{$\mathrm{Ca}^{2+}$ dependence}

It is well established that $\mathrm{Ca}^{2+}$ is essential for both, activity and binding of phospholipases to their substrate $[34,35]$. In order to investigate the effect of $\mathrm{Ca}^{2+}$ on CDPL activity, we studied the variation of the PC emulsion hydrolysis rates by homogeneous SPLA2 in presence of various $\mathrm{Ca}^{2+}$ concentrations (Figure 4A). For further comparison, we reported in the same Figure 4A the results obtained with DrPLA2 and OPLA2. Our results show that PLA2 activity could not be detected in the presence of chelator such as EDTA or EGTA when pure PC or egg yolk emulsion was used as substrate. The specific activity of SPLA2 increased to reach its maximum in the presence of $8 \mathrm{mM} \mathrm{Ca}^{2+}$ using PC as substrate (figure 4A). Similar results were obtained with MSDPL [30] and CDPL [28]. This $\mathrm{Ca}^{2+}$ concentration is also needed to activate mammal and bird pancreatic PLA2 [20-23].

\section{Bile salts dependence}

Several studies have provided evidence that bile salts are tensioactive agents ensuring in micellar form, the dispersion of the hydrolysis products and thus increase the hydrolysis rate. De Haas et al. (1970) [36] reported that micellar forms of the substrate were hydrolyzed by PLA2 at a much higher rate than molecularly dispersed substrates. In order to investigate the effect of bile salts on SPLA2 activity, the rate of hydrolysis of PC by SPLA2 with various concentrations of bile salts, at $\mathrm{pH} 8.5$ and at $40{ }^{\circ} \mathrm{C}$, was studied. As shown in figure $4 \mathrm{C}$ and $4 \mathrm{D}$, sodium Taurodeoxycholate (NaTDC) and sodium deoxycholate $(\mathrm{NaDC})$ were specifically required for SPLA2 activity. The maximum phospholipase activity was observed in the presence of $4 \mathrm{mM}$ NaTDC or $6 \mathrm{mM}$ 

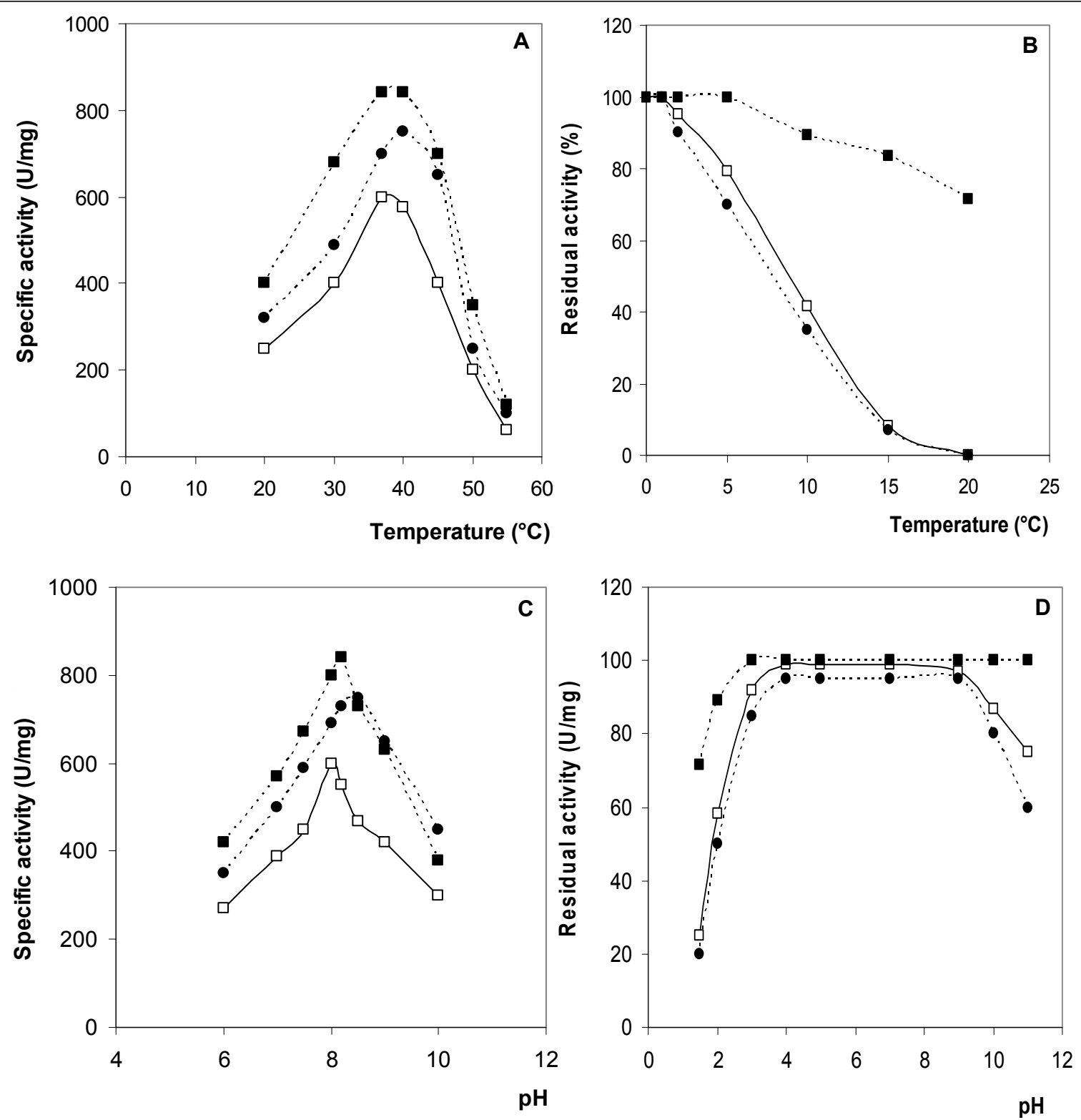

Figure 3 Effect of temperature and pH. (A) Effect of temperature on SPLA2, OPLA2 and DrPLA2 activity. (B) Effect of temperature on SPLA2, OPLA2 and DrPLA2 stability. The enzyme activity was tested at various temperatures using PC as substrate in the presence of $10 \mathrm{mM} C{ }^{2+}$ and $4 \mathrm{mM} \mathrm{NaDC}$ and at standard conditions after incubation at $70^{\circ} \mathrm{C}$ at different times. (C) Effects of pH on SPLA2, OPLA2 and DrPLA2 activity and stability. (D) Effects of $\mathrm{pH}$ on SPLA2, OPLA2 and DrPLA2 activity and stability. The enzyme activity was tested at various $\mathrm{pH}$ using PC as substrate in the presence of $10 \mathrm{mM} \mathrm{Ca}^{2+}$ and $4 \mathrm{mM} \mathrm{NaDC}$ and at standard conditions after incubation at different $\mathrm{pH}$. All experiments were repeated at least three times. SPLA2 (black circle); DrPLA2 (black square); OPLA2 (open square).

NaDC. These observations corroborate with previous findings with mammals, bird pancreatic PLA2 [20-23].

\section{Kinetic parameters}

To determine the kinetic parameters of SPLA2, the rate of hydrolysis of different concentrations of PC were measured under optimal conditions (4 mM NaTDC, $8 \mathrm{mM}$, $\mathrm{CaCl}_{2}, \mathrm{pH} 8,5$ and $40^{\circ} \mathrm{C}$ ). The Lineweaver-Burk curves were plotted (data not shown). From these fits, the substrate affinity constants $\left(\mathrm{K}_{\mathrm{M}}\right)$ and the turnover of the enzymatic reaction $\left(\mathrm{k}_{\mathrm{cat}}\right)$ were obtained and shown with the deduced catalytic efficiency $\left(\mathrm{k}_{\mathrm{cat}} / \mathrm{K}_{\mathrm{M}}\right)$ in Table 3. For further comparison, we reported in the same Table 3 the kinetic parameters values obtained with DrPLA2, under the same conditions. From these values, one can say that SPLA2 hydrolyses the PC substrate more efficiently than SPLA2 since the ratio representing the catalytic efficiency $\left(\mathrm{K}_{\mathrm{cat}} / \mathrm{K}_{\mathrm{m}}\right)$ is about 2 times higher with SPLA2 than with DrPLA2. 

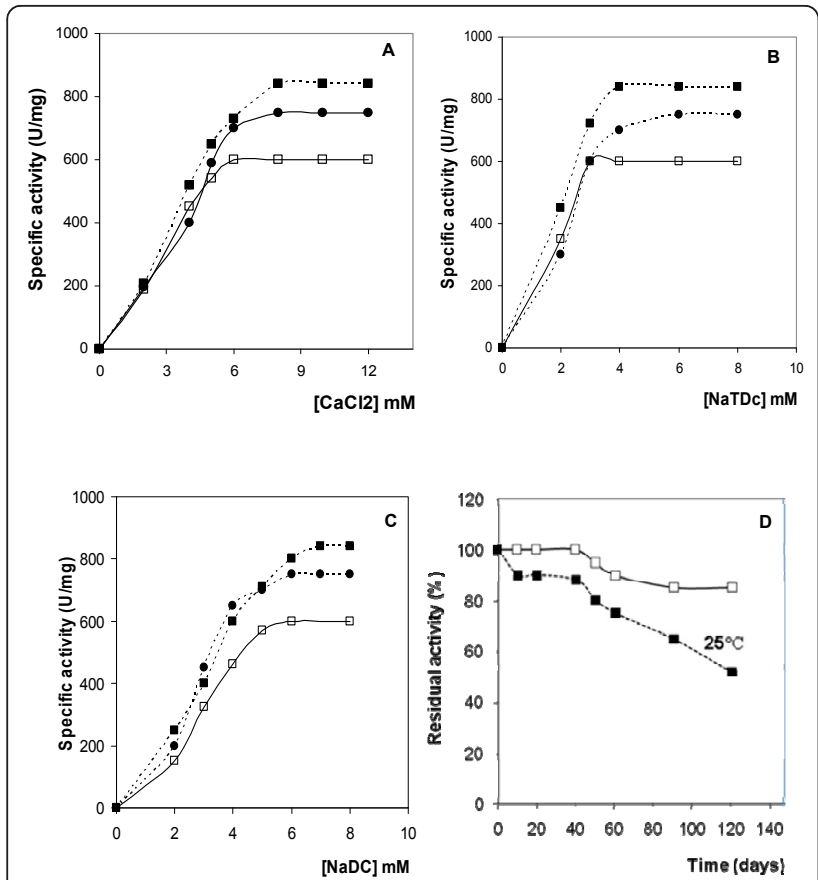

Figure 4 Biochemical properties of SPLA2 compared with these of OPLA2 and DrPLA2. (A) Effect of $\mathrm{Ca}^{2+}$ concentration on SPLA2, OPLA2 and DrPLA2 activity. Enzyme activity was measured at various concentrations of $\mathrm{Ca}^{2+}$ using $\mathrm{PC}$ as substrate at $\mathrm{pH} 8.5$ and at $40^{\circ} \mathrm{C}$ in the presence of $4 \mathrm{mM} \mathrm{NaTDC}$. The star symbol indicates the absence of phospholipase activity checked in the absence of $\mathrm{CaCl}_{2}$ and in the presence of $10 \mathrm{mM}$ EDTA. (B) Effect of increasing concentration of NaTDC on SPLA2, OPLA2 and DrPLA2 activities. (C) Effect of increasing concentration of NaDC on SPLA2, OPLA2 and DrPLA2 activities. PLA2 activity was measured using PC emulsion as substrate at under standard conditions. (D) Long-term stability of SPLA2 stored in the refrigerator $\left(5^{\circ} \mathrm{C}\right)$ and at room temperature $(25$ $\left.{ }^{\circ} \mathrm{C}\right)$. Assays were carried out under standard conditions as described in the text. SPLA2 (black circle); DrPLA2 (black square); OPLA2 (open square). All experiments were repeated at least three times.

\section{Effects of organic solvents}

Organic solvents can be advantageous in various industrial enzymatic processes. The use of organic solvents can increase the solubility of non-polar substrates, increase the thermal stability of enzymes, decrease water-dependent side reactions, or eliminate microbial contamination [37]. In this study, the SPLA2 showed high stability in the presence of water-miscible organic solvents, since it retained almost $100 \%$ activity after exposure, for $2 \mathrm{~h}$ at $25{ }^{\circ} \mathrm{C}$, to $50 \%$ methanol, $50 \%$

Table 3 Apparent kinetic parameters of SPLA2, and dromedary pancreatic phospholipase $A_{2}$ (DrPLA2)

\begin{tabular}{ccccc}
\hline Phospholipase & $\begin{array}{c}\mathbf{V}_{\text {max }} \\
(\mathbf{U} / \mathbf{m g})\end{array}$ & $\begin{array}{c}\mathrm{K}_{\mathrm{m}} \\
(\mathbf{m M})\end{array}$ & $\begin{array}{c}\mathrm{K}_{\text {cat }} \\
\left(\mathbf{s}^{-1}\right)\end{array}$ & $\begin{array}{c}\mathrm{K}_{\mathrm{cat}} / \mathrm{K}_{\mathrm{m}} \\
\left(\mathbf{m M}^{-1} \mathbf{s}^{-\mathbf{1}}\right)\end{array}$ \\
\hline SPLA2 & 750 & 17 & 187 & 11 \\
\hline DrPLA2 & 600 & 22 & 140 & 6.36 \\
\hline
\end{tabular}

ethanol, 50\% 2-propanol, $50 \%$ acetonitrile or $50 \%$ acetone (Table 4). Addition of $50 \%$ ethanol or $50 \%$ acetonitrile to the pure SPLA2 caused a $12 \%$ immediate increase of the PLA2 activity in comparison to the control.

\section{Long-term stability}

In the course of the long-term stability experiment, the activity of SPLA2, which was stored at room temperature, did not decrease within the two first days (Figure 3). During the first week, activity did not drop below $90 \%$ of initial values. Later on, a continuous decrease was evident towards $50 \%$ of initial activity after 120 days. In contrast, the samples stored in the refrigerator maintained more than $90 \%$ of initial activity after 120 days. In conclusion, SPLA2 activity remained surprisingly stable up to 40 weeks, although SPLA2 was not maintained in a stability-enhancing medium, e.g. supplements of $\mathrm{Ca}^{2+}$, glycerol, or ammonium sulphate, but just in plain demineralized water.

\section{Materiels and methods}

\section{Materials}

Benzamidine was from Fluka (Buchs, Switzerland), bovine serum albumine (BSA), sodium deoxycholate $(\mathrm{NaDC})$, sodium taurodeoxycholate $(\mathrm{NaTDC})$, Triton X-100 (TX-100) and phosphatidylcholine (PC) were from Sigma Chemical (St. Louis, USA), acrylamide and bis-acrylamide electrophoresis grade were from $\mathrm{BDH}$ (Poole, UK). Marker proteins and the chromatography supports, used for PLA2 purification: Sephadex G-50, Mono-S, Mono-Q were Pharmacia (Uppsala, Sweden).). PVDF membrane and protein sequencer Procise 492 equipped with $140 \mathrm{C}$ HPLC system purchased from Applied Biosystems (Roissy, France). C-8 reverse-phase eurospher 100 column was from Knauer (Germany). $\mathrm{pH}$-stat was from Metrohm (Herisau, Switzerland).

\section{Pancreas collections}

Stingrays (Dasyatis pastinaca) pancreases were collected from a local fish market (Sfax, Tunisia) and stored at $-20^{\circ} \mathrm{C}$.

Table 4 stability of SPLA2 in organic solvents

\begin{tabular}{ccc}
\hline Organic solvent & Relative activity\% (1 $\mathbf{~})$ & Relative activity\% (2 h) \\
\hline Control & $100 \pm 0.5$ & $100 \pm 2.4$ \\
\hline Acetone & $95 \pm 2.5$ & $92 \pm 2.2$ \\
\hline Acetonitrile & $105 \pm 1.5$ & $105 \pm 2.3$ \\
\hline Methanol & $98 \pm 2.4$ & $95 \pm 1.9$ \\
\hline Ethanol & $116 \pm 2.7$ & $100 \pm 3.3$ \\
\hline 2-Propanol & $97 \pm 3.1$ & $93 \pm 3.6$ \\
\hline Pure SPLA2 was incubated in each organic solvent (50\%) at $30{ }^{\circ} \mathrm{C}$ for 1 or \\
2 hours. \\
The experiments were conducted three times.
\end{tabular}




\section{Determination of phospholipase activity}

The stingray PLA2 activity was measured titrimetrically at $\mathrm{pH} 8.5$ and at $40{ }^{\circ} \mathrm{C}$ with a $\mathrm{pH}$-stat, under the optimum conditions, using purified egg PC or a crude egg yolk emulsions as substrate in the presence of $4 \mathrm{mM}$ $\mathrm{NaTDC}$ and $8 \mathrm{mM} \mathrm{CaCl}_{2}$ [38]. Some assays were performed with $\mathrm{NaDC}$. One unit of phospholipase activity was defined as $1 \mu$ mole of fatty acid liberated under standard conditions.

\section{Effects of temperature and $\mathrm{pH}$ on SPLA2 stability}

In order to check the thermal stability of SPLA2, homogeneous enzyme was incubated successively at $70{ }^{\circ} \mathrm{C}$ for different durations. The $\mathrm{pH}$ stability of SPLA2 was studied at room temperature during $30 \mathrm{~min}$ using the following buffers: $50 \mathrm{mM}$ sodium acetate buffer (pH 4-6), $50 \mathrm{mM}$ potassium phosphate buffer ( $\mathrm{pH} 6-8), 50 \mathrm{mM}$ Tris- $\mathrm{HCl}$ buffer (pH 7-10). After each incubation, residual phospholipase activity was measured after centrifugation of the sample, under optimal conditions.

\section{Determination of protein concentration}

Protein concentration was determined as described by Bradford (1976) using BSA $\left(\mathrm{E}^{1 \%}{ }_{1 \mathrm{~cm}}=6.7\right)$ as reference [33].

\section{Oligosaccharide content}

The presence of glycan chains in the purified cofactors was checked by the anthrone-sulfuric acid method using glucose as a standard [39]. One milliliter of each pure SPLA2 $(1 \mathrm{mg} / \mathrm{ml}$ in Tris-HCl buffer) was mixed with $4 \mathrm{ml}$ of distilled water in screw cap type culture tube. The tube was then placed on ice to cool. Then, we added $10 \mathrm{ml}$ of cold anthrone reagent $(0.2 \mathrm{~g}$ in $100 \mathrm{ml}$ concentrated $\mathrm{H}_{2} \mathrm{SO}_{4}$ ) prepared fresh daily. After mixing, we placed a marble on top of the tube to prevent evaporation and we incubated in a boiling water bath during $16 \mathrm{~min}$, afterwards, the tube was cooled on ice for 2-3 min then at room temperature for 5-10 min. Finally, we read the absorbance at $620 \mathrm{~nm}$ against a reagent blank. The rate of glycosylation is calculated on the basis of percentage by weight.

\section{Alkylation of cysteine residues}

The alkylation of cysteine residues of phospholipase was realized as described by Okazaki et al. (1985) [40]. Hundred picomoles of SPLA2 in $1 \mathrm{ml}$ of $10 \mathrm{mM}$ Tris- $\mathrm{HCl}$, $\mathrm{pH} 8$ were denatured in $185 \mu \mathrm{l}$ of $8 \mathrm{M}$ guanidine hydrochloride, $65 \mu \mathrm{l}$ of $1 \mathrm{M}$ Tris- $\mathrm{HCl}, 4 \mathrm{mM}$ EDTA (pH 8.5) and $80 \mathrm{mM}$ DTT for $30 \mathrm{~min}$ at $60{ }^{\circ} \mathrm{C}$. S-Pyridylethylation of cysteine residues of protein was performed by adding $4 \mu \mathrm{l}$ of vinyl pyridine and incubation at $25{ }^{\circ} \mathrm{C}$ for $3 \mathrm{~h}$. The modified enzyme was dialyzed against water for $\mathrm{N}$-terminal sequencing.

\section{Analytical methods}

Analytical polyacrylamide gel electrophoresis of proteins in the presence of sodium dodecyl sulfate (SDS-PAGE) was performed by the method of Laemmli (1970) [41]. The proteins were stained with Coomassie brilliant blue.

\section{Amino acid sequencing}

For N-terminal sequencing, the purified enzyme was blotted $\left(60 \mathrm{~min}, 50 \mathrm{~mA}, 4{ }^{\circ} \mathrm{C}\right.$ ) onto a PVDF (polyvinylidene difluoride) membrane (Applied Biosystems, ProBlotTM) in $20 \mathrm{mM}$ CAPS buffer (pH 11) containing $10 \%$ methanol using a mini trans-blot cell (BioRad, Hercules, USA). The N-terminal sequence was determined by automated Edman's degradation, using an Applied Biosystems Protein Sequencer Procise 492 equipped with 140 C HPLC system (Roissy, France) [42].

\section{Conclusion}

Described here is the purification and the characterization of a new phospholipase A2 from stingray pancreas. This phospholipase has several advantageous features for industrial applications. Stability of SPLA2 in the presence of organic solvents, and its tolerance to high temperatures, basic and acidic $\mathrm{pH}$, makes it a good candidate for application in food industry to treat phospholipid-rich industrial effluents, or to synthesize useful chemical compounds.

\section{Abbreviations}

AA: Arachidonic acid; DrPLA2: dromedary phospholipase A2; $\mathrm{k}_{\text {cat: }}$ : the turnover of the enzymatic reaction; $K_{M}$ : substrate affinity constants; NaTDC: sodium taurodeoxycholate; OPLA2: ostrich phospholipase A2; PLA2: phospholipase A2; SPLA2: stingray phospholipase A2, sPLA2-IB: secreted pancreatic phospholipase $\mathrm{A} 2$;

\section{Acknowledgements}

This work was supported by DGRST granted to the "Laboratoire de Biochimie et de Génie Enzymatique des Lipases". The authors would like to thank to Mr. Chedly Youssfi (FSS) for his technical assistances. Our thanks are due to $\operatorname{Pr~H}$. Mejdoub (FSS, Tunisia) for the sequencing of the $\mathrm{NH}$-terminal of SLA2.

\section{Authors' contributions}

$A B B$ and $A K$ carried out all the studies, analyzed the data and drafted the manuscript. EB helped with the analysis of the data. YG helped with the discussion of the data and the correction of the manuscript. YBA participated in the study design and helped to draft the manuscript. All authors have read and approved the final manuscript.

\section{Competing interests}

The authors declare that they have no competing interests.

Received: 25 January 2011 Accepted: 17 February 2011

Published: 17 February 2011

\section{References}

1. Balsinde J, Winstead MV, Dennis EA: Phospholipase A2 regulation of arachidonic acid mobilization. FEBS Lett 2002, 531:2-6

2. Chakraborti S: Phospholipase A2 isoforms: a perspective. Cell Signalling 2003, 15:637-665. 
3. Balsinde J, Balboa MA, Insel PA, Dennis EA: Regulation and inhibition of phospholipase A2. Annu Rev Pharmacol Toxicol 1999, 39:175-189.

4. Murakami M, Kudo I: Diversity and regulatory functions of mammalian secretory phospholipase $\mathrm{A}_{2}$ s. Advances in Immunology 2001, 77:163-194.

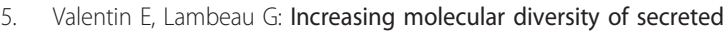
phospholipases $A_{2}$ and their receptors and binding proteins. Biochim Biophys Acta 2000, 1488:59-70.

6. Derewenda ZS, Ho YS: PAF-acetylhydrolases. Biochim Biophys Acta 1999, 1441:229-236.

7. Valentin E, Ghomashchi F, Gelb MH, Lazdunski M, Lambeau G: On the diversity of secreted phospholipases A2. Cloning, tissue distribution, and functional expression of two novel mouse group II enzymes. J Biol Chem 1999, 274:31195-31202.

8. Mandal AK, Zhang Z, Chou JY, Zimonjic D, Keck CL, Popescu N, Mukherjee $A B$ : Molecular characterization of murine pancreatic phospholipase A(2). DNA Cell Biol 2001, 20:149-157.

9. Kolko M, Prause JU, Bazan NG, Heegaard S: Human secretory phosp holipase A(2), group IB in normal eyes and in eye diseases. Acta Ophthalmol Scand 2007, 85:317-323.

10. Hanasaki K, Yokota Y, Ishizaki J, Itoh T, Arita H: Resistance to endotoxic shock in phospholipase $A_{2}$ receptor-deficient mice. J Biol Chem 1997, 272:32792-32797.

11. Lambeau $\mathrm{GH}$, Cupillard $L$, Ladzunski M: Membrane receptors for venom phospholipase $\mathrm{A}_{2}$. In Venom Phospholipase A2 Enzymes: Structure, Function and Mechanism. Edited by: Lambeau GH, Cupillard L and Ladzunski MJ. Wiley 1997:389-412.

12. Kobeghenova SS: Morphology and morphogenesis of the digestive system of some cartilaginous fishes (Chondrichthyes). Zoological journal 1992, 71:108-122.

13. Hanasaki K, Yakota Y, Ishizaki J, Johnson LK: Resistance to endotoxic shock in phospholipase A2 receptor-deficient mice. J Biol Chem 1997, 272:32792.

14. Nieuwenhuizen W, Kunze $H$, de Haas GH: Phospholipase A2 (phosphatide acylhydrolase EC 3.1.1.4) from porcine pancreas. Methods Enzymol 1974, 321:147.

15. Abita JP, Lazdunski M, Bonsen PPM, Pieterson WA, de Haas GH: Zymogenenzyme transformations. On the mechanism of activation of prophospholipase A. Eur J Biochem 1972, 30:37.

16. Arnesjö B, Barrowman J, Borgström B: The zymogen of phospholipase A2 in rat pancreatic juice. Acta Chem Scand 1967, 21:2897.

17. Figarella C, Clemente F, Guy O: A zymogen of phospholipase A in human pancreatic juice. Biochem Biophys Acta 1971, 227:213.

18. Dutilh E, Van Doren PJ, Verheul EE, de Haas GH: Isolation and Properties of Prophospholipase A2 from Ox and Sheep Pancreas. Eur J Biochem 1975, 53:91.

19. Evenberg A, Meyer H, Verheij HM, de Haas GH: Isolation and properties of prophospholipase A2 and phospholipase A2 from horse pancreas and horse pancreatic juice. Biochim Biophys Acta 1977, 491:265

20. Ben Bacha A, Gargouri Y, Bezzine S, Mejdoub H: Purification and biochemical characterization of phospholipase A2 from dromedary pancreas. Biochim Biophys Acta 2006, 1760:1202

21. Ben Salah $\mathrm{R}$, Zouari $\mathrm{N}$, Reinbolt J, Mejdoub H: Purification of turkey pancreatic phospholipase A2. Biotechnol Biochem 2003, 67:2139.

22. Ben Bacha A, Gargouri Y, Bezzine S, Mosbah H, Mejdoub H: Ostrich pancreatic phospholipase $A_{2}$ : Purification and biochemical characterization. Journal of Chromatography B 2007, 857:108-114.

23. Karray A, Frikha F, Ben Bacha A, Ben Ali Y, Gargouri Y, Bezzine S: Biochemical and molecular characterization of purified chicken pancreatic phospholipase A2. FEBS J 2009, 276(16):4545-54.

24. Audley MA, Shetty KJ, Kinsella JE: Isolation and properties of phospholipase A from pollock muscle. J Food Sci 1978, 43: 771-1775.

25. Neas NP, Hazel JR: Partial purification and kinetic characterization of the microsomal phospholipase $A_{2}$ from thermally acclimated rainbow trout (Salmo gairdneri). J Comp Physiol B 1985, 155:461-469.

26. Aaen $B$, Jessen $F$, Jensen $B$ : Partial purification and characterization of a cellular acidic phospholipase $A_{2}$ from cod (Gadus morhua). Comp Biochem Physiol B 1995, 110:547-554.

27. Zambonino Infante $J$, Cahu CL: High dietary lipid levels enhance digestive tract maturation and improve Dicentrarchus labrax larval development. J Nutr 1999, 129:1195-1200.
28. Cherif S, Ben Bacha A, Ben Ali Y, Horchani H, Rekik W, Gargouri Y: Crab digestive phospholipase: a new invertebrate member. Bioresour Technol 2010, 101(1):366-71.

29. Pattus F, Slotboom AJ, de Haas GH: Regulation of Phospholipase A2 Activity by the Lipid-Water Interface: a Monolayer Approach. Biochemistry 1979, , 18: 2703-2707.

30. Zarai Z, Ben Bacha A, Horchani H, Bezzine S, Gargouri Y, Mejdoub H: A novel marine hepatopancreatic phospholipase $A 2$ with digestive and toxic activities. Archives of Biochemistry and Biophysics 2010, 494(2):121-129.

31. Verheij HM, Slotboom AJ, de Haas GH: Structure and function of phospholipase A2. Rev Physiol Biochem Pharmacol 1981, 91:91.

32. Kishimura $\mathrm{H}$, Hayashi $\mathrm{K}$ : Isolation and characteristics of trypsin from pyloric ceca of the starfish Asterina pectinifera. Comp Biochem Physiol B Biochem Mol Biol 1999, 124: 483-488.

33. Bradford MM: A rapid and sensitive method for the quantification of microgram quantities of proteins utilizing the principle of protein-dye binding. Anal Biochem 1976, 72:248-254.

34. Scott DL, White SP, Otwinowski Z, Yuan W, Gelb MH, Sigler PB: Crystal structure of bee venom phospholipase $\mathrm{A} 2$ in a complex with a transition-state analogue. Science 1991, 250:1541-1546.

35. Fleer EM, Verheij HM, De Haas GH: Modification of arginine residues in bovine pancreatic phospholipase $A 2$, identification of aspartate 49 as $\mathrm{Ca}^{2+}$ binding ligand. Eur J Biochem 1981, 113:283-288.

36. De Haas GH, Slotboom A, Bonsen PPM, Van Deenen LLM, Maroux S, Puigserver A, Desnuelle P: Studies on phospholipase A and its zymogen from porcine pancreas: I. The complete amino acid sequence. Biochim Biophys Acta 1970, 221:31-53.

37. Heitmann P:Edited by: Ruttloff H. Industrielle Enzyme, Behr's Verlag, Hamburg; 1994:913.

38. Abousalham A, Verger R: Egg yolk lipoproteins as substrates for lipases. Biochim Biophys Acta 2000, 1485:56-62.

39. Spiro R: Analysis of sugar found in glycoprotein. Methods Enzymol 1966, 3-26.

40. Okazaki K, Yamada H, Imoto T: A convenient S-2 aminoethylation of cysteinyl residues in reduced proteins. Anal Biochem 1985, 149:516-520.

41. Laemmli UK: Cleavage of structural protein during the assembly of the head of bacteriophage T4. Nature 1970, 227:680-685.

42. Hewick RM, Hunkapiller MW, Hood LE: A gaz-liquid solid phase peptide and protein sequenator. J Biol Chem 1981, 256:7990-7997.

\section{doi:10.1186/1476-511X-10-32}

Cite this article as: Bacha et al:: Purification and biochemical

characterization of pancreatic phospholipase A2 from the common stingray Dasyatis pastinaca. Lipids in Health and Disease 2011 10:32.

\section{Submit your next manuscript to BioMed Central and take full advantage of:}

- Convenient online submission

- Thorough peer review

- No space constraints or color figure charges

- Immediate publication on acceptance

- Inclusion in PubMed, CAS, Scopus and Google Scholar

- Research which is freely available for redistribution

Submit your manuscript at www biomedcentral com/submit
C Biomed Central 